\title{
KONSEP MAHAR (MASKAWIN) \\ DALAM TAFSIR KONTEMPORER
}

\author{
Halimah B. \\ Fakultas Syariah dan Hukum Universitas Islam Negeri (UIN) Alauddin Makassar
}

\begin{abstract}
:
Some assume, and already settled in the subconscious of society that dowry (dowry) is the price a husband must pay to obtain privileges towards his wife. Of course this is a false religious phenomenon. This assumption has very negative implications on the survival of family life. The wife is the property of a husband because of the property he has given. But in the contemporary interpretation it is clear that the dowry is a treasure that must be handed a husband to the wife at the marriage ceremony. It is therefore established that the dowry is the absolute right of the wife and the dowry is not a sale and purchase transaction.
\end{abstract}

Keywords:

Mahar, Shadaq, Nihlah, Justice, Contemporary Interpretation.

\begin{abstract}
Abstrak:
Sebagian kalangan berasumsi, dan sudah mengendap di alam bawah sadar masyarakat bahwa mahar (maskawin) adalah harga yang harus dibayar seorang suami untuk memperoleh hak-hak istimewa terhadap istrinya. Tentu ini adalah sebuah fenomena keagamaan yang keliru. Asumsi ini berimplikasi sangat negatif pada kelangsungan kehidupan keluarga. Istri seakan-akan adalah hak milik seorang suami disebabkan harta yang telah ia berikan. Namun dalam tafsir kontemporer sangat jelas bahwa mahar adalah harta yang wajib diserahkan seorang suami kepada istri pada saat akad nikah. Karena itu ditetapkan bahwa mahar adalah hak mutlak istri dan mahar bukan transaksi jual beli.
\end{abstract}

Kata Kunci:

Mahar, shadaq, nihlah, keadilan, tafsir kontemporer.

\section{A. PENDAHULUAN}

$\mathrm{M}$ ahar (maskawin) sudah dikenal pada masa jahiliyah, jauh sebelum Islam datang. Akan tetapi, mahar sebelum datangnya Islam bukan diperuntukkan bagi calon istri, melainkan untuk ayah atau kerabat dekat laki-laki dari pihak istri. Konsep perkawinan menurut berbagai bentuk hukum adat 
ketika itu, sama dengan transaksi jual beli, yakni jual beli antara calon suami sebagai pembeli dan ayah atau keluarga dekat laki-laki dari calon istri sebagai pemilik barang. Ketika itu, wali yaitu ayah atau kakek dan keluarga dekat yang menjaga perempuan menganggap mahar adalah hak mereka sebagai imbalan atas tugas menjaga dan membesarkan perempuan tersebut. Karena apabila perempuan tersebut dikawinkan, mahar yang diberikan oleh mempelai laki-laki akan menjadi milik wali atau penjaganya. Secara tidak langsung mahar digambarkan sebagai pembelian perempuan ${ }^{2}$.

Ketika al-Qur'an datang pranata mahar tetap dilanjutkan, hanya saja konsepnya mengalami perubahan. Sebelum Islam mahar dibayarkan kepada orang tua calon istri, maka sekarang mahar tersebut diperuntukkan bagi calon istri. Dengan demikian menurut Nasaruddin Umar, al-Qur'an mengubah status perempuan dari sebuah "komoditi" barang dagangan menjadi subyek yang ikut terlibat dalam suatu kontrak $^{3}$, bahkan menunjukkan Syariat Islam mempunyai sistem mahar tersendiri berdasarkan prinsip keadilan dan maslahah. ${ }^{4}$ Murtadha Muthahhari (1919-1979) berpendapat bahwa mahar adalah milik perempuan an sich, bukan milik ayah atau saudara laki-lakinya, karena mahar disebut sebagai sa\}duqat yang merupakan pemberian penuh kerelaan kepada perempuan ${ }^{5}$, disebutkan dalam QS. al-Qur'an (alNisa'> (4): 4:

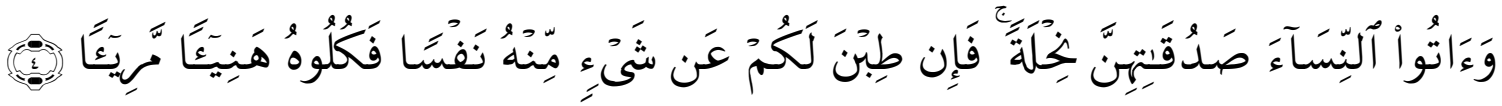

Terjemahnya:

Berikanlah maskawin (mahar) kepada perempuan (yang kamu nikahi) sebagai pemberian dengan penuh kerelaan. Kemudian jika mereka menyerahkan kepada kamu sebagian dari maskawin itu dengan senang hati maka makanlah (ambillah) pemberian itu (sebagai makanan) yang sedap lagi baik akibatnya6.

Perintah untuk memberikan mahar kepada istri adalah hak istimewa yang diberikan Tuhan kepada perempuan. Dengan diberikannya hak mahar sebagai hak eksklusif perempuan di mana pihak lain tidak turut campur, mengisyaratkan prinsip bahwa perempuan mampu bertanggung jawab atas apa yang menjadi haknya. Namun sangat disayangkan, masih ada kecenderungan dari masyarakat zaman sekarang pihak keluarga mempelai perempuan membelanjakan mahar untuk

\footnotetext{
${ }^{1}$ Nasaruddin Umar, Ketika Fikih Membela Perempuan (Jakarta: PT.Gramedia, 2014), 101.

${ }^{2}$ Murtadha Muthahhari, The Right of Women in Islam (Teheran: World Organization for Islamic Services, 1980), 204.

${ }^{3}$ Nasaruddin Umar, Ketika Fikih Membela Perempuan, 101.

${ }^{4}$ Hasbi.Hj.Muh.Ali, Raihanah Hj.Azahari,“Objektif Syariah dalam Pemberian Mahar”dalam Internatonal Journal Fiqh,No.10(2013),59.http://umexpert.um.edu.my/file/publication/00002815_95293-pdf.(diakses 25 Nopember 2015).

${ }^{5}$ Murtadha Muthahhari, Nizam Huquq al-Mar'ah fi al-Islam (Teheran: Markaz I'lam al-Zikra al-Sadisah li Intishari al-Thawrah al-Islamiyah, 1985), 172.

${ }^{6}$ Departemen Agama RI, al-Qur'an dan Terjemahnya (Jakarta: Yayasan Penyelenggara Penterjemah/Penafsir al-Qur'ān, 1971), 115.
} 
membeli barang dan alat rumah tangga. Hal tersebut boleh saja asalkan atas persetujuan dari mempelai perempuan.

\section{B. HAKEKAT MAHAR}

Menurut Wahbah al-Zuhayli (L.1932) mahar adalah harta yang merupakan hak istri yang diberikan oleh suami sebab akad pernikahan atau hubungan badan(persetubuhan)secara hakiki. ${ }^{7}$ Dalam fiqh Islam, selain kata mahar, terdapat sejumlah istilah lain yang mempunyai konotasi yanga sama yaitu: shadaq ${ }^{8}$, nihlah ${ }^{9}$, ujr ${ }^{10}$, faridhah ${ }^{11}$, hiba', uqar, 'alaiq, thaw ${ }^{12}$ dan nikah. ${ }^{13}$ Keseluruhan istilah tersebut membawa maksud dan pengertian yang hampir sama, yaitu pemberian secara sukarela tanpa mengharapkan imbalan.

Kata Saduqat adalah bentuk jamak dari saduqah dengan dhommah huruf dal yang artinya mahar perempuan, berasal dari kata sadaqa karena ia merupakan pemberian yang didahului oleh janji yang dipenuhi oleh si pemberi. Kata nihlah dengan kasrah huruf nun; berarti pemberian tanpa ada tujuan penggantian, dan dikatakan pula nuhlah dengan d\}ommah huruf nun. ${ }^{14}$ Senada dengan al-Qurthubi (w.671 H.) mengartikan kata" nihlah" sebagai pemberian dengan penuh kerelaan. Alnihlah dan al-nuhlah dengan mengkasrahkan dan mend\}ammah-kan huruf nun, keduanya sering digunakan dalam bahsa Arab, dan maknanya adalah pemberian ${ }^{15}$.

${ }^{7}$ Wahbah al-Zuhayli al-Fiqh al-Islami wa Adillatuh (Damaskus: Dar al-Fikr, 1989), Jilid 7, 251. Baca juga 'Abd al-Karim Zaydan, al-Mufașal fi Ahkam al-Mar'ah wa al-Bayt al-Muslim fi al-Shari 'ah al-Islamiyah (Beyrut: Mu'assasah al-Risalah, 1993), Jilid 7, 49. Baca juga Husein Muhammad, Fiqh Perempuan Refleksi Kiai atas Wacana Agama dan Gender (Yogyakarta: LKIS,2001), 108. Lihat pula Muhammad Baqir, Fiqih Praktis II Menurut Al-Qur'ān, al-Sunnah dan Pendapat para Ulama (Bandung: Karisma, 2008), 131.

${ }^{8} \mathrm{QS}$. al-Nisa'(4):4.

${ }^{9}$ QS. al-Nisa' (4):4.

${ }^{10}$ QS.al-Nisa' (4):24

${ }^{11}$ QS.al-Baqarah (2): 230.

${ }^{12}$ QS.al-Nisa'(4): 25.

${ }^{13}$ Wahbah al-Zuhayli, al-Fiqh al-Islami wa Adillatuh, Jilid, 7, 251. Lihat Husein Muhammad, Fiqh Perempuan Refleksi Kiai atas Wacana Agama dan Gender, 109. Baca Amir Syarifuddin, Hukum Perkawinan Islam di Indoneesia Antara Fiqh Munakahat dan Undang-Undang Perkawinan (Jakarta: Prenada Media, 2007), Cet. 2, 84. ZaitunahSubhan, Menggagas Fiqh Pemberdayaan Perempuan (Jakarta: el-KAHFI, 2008), 223.

${ }^{14}$ Muhammad Thahir Ibnu 'Asyur, al-Tahrir wa al-Tanwir (Tunis: Dar Sahnun li al-Nashr wa al-Tawzi', t.th.), Jilid 4, 230. Kata nihlatan dibaca nasab karena kedudukannya sebagai hal dari ayat (saduqatihinna), akan tetapi boleh saja hal disebutkan dalam bentuk mufrad (tunggal) meskipun sahibul halnya bentuk jamak (banyak), karena yang dikehendaki dari bentuk mufrad ini adalah jenis yang tepat untuk seluruh individu, dan boleh juga kata nihlatan dibaca nasab sebagai masdariyah untuk kata (اتوا) untuk menjelaskan jenis pemberian yang maksudnya memberikan kemuliaan. Muhammad Thahir Ibnu 'Asyur, al-Tahrir wa al-Tanwir, Jilid 4, 230.

${ }^{15} \mathrm{Abu}$ Abdillah Muhammad bin Ahmad al-Anshari al-Qurthubi, al-Jami ' li Ahkam al-Qur'an, (Beirut: Dar al-Kutub al-'Ilmiyah, t.th.), 1594. Al-Raghib al-Ashfahani menjelaskan kata al-nahlah dan al-nihlah adalah pemberian sukarela dan pemberian ini berbeda dengan hibah, sebab setiap hibah sudah pasti termasuk nihlah, sedangkan tidak setiap nihlah adalah hibah. Menurutnya kata nihlah diambil dari kata al-nahl apabila dilihat dari fi'il seperti, nahaltahu athaytuhu 'athiyyah artinya saya memberikannya sebuah pemberian, maka hal itu dinamakan dengan mahar, ini bermakna bahwa seorang laki-laki yang menikahi wanita tidak berhak menggaulinya sampai ia memberikan mahar sebagai pengganti kehormatan dirinya, demikian juga pemberian seorang laki-laki terhadap anaknya. Baca al-Raghib al-Aṣfahani, Mu'jam Mufradāt Alfaz al-Qur'an (Beirut: Dār al-Fikr, t.th.), 506. 
Sementara al-Thabari makna (wa atu al-nisa saduqatihinna nihlah) sebagai pemberian dengan penuh kerelaan " ditujukan kepada para wali perempuan bukan kepada suaminya ${ }^{16}$.

Muhammad 'Abduh kata nihlah adalah sebuah pemberian ikhlas tanpa mengharap balasan. Sementara kata saduqat adalah bentuk jamak dari kata sadaqah adalah persembahan yang diberikan kepada perempuan dengan cara sukarela sebelum melakukan hubungan badan. Atas dasar ini, kata nihlah (pemberian) muncul sebagai bentuk ekspresi kasih sayang dan ikatan kekerabatan yang wajib dan tidak dapat ditawar-tawar seperti layaknya transaksi jual beli. Hal yang sering terjadi dalam masyarakat di mana laki-laki hanya semata-mata memberi mahar seperti layaknya hadiah biasa tanpa disertai perasaan kasih sayang dan rasa kekerabatan. ${ }^{17}$

Pandangan yang senada dijelaskan Khairuddin Nasution kata nihlah memberikan pengertian bahwa status dari pemberian dalam perkawinan adalah suatu pemberian sukarela tanpa pamrih sebagai simbol cinta dan kasih sayang dari calon suami kepada calon istrinya, dan bukan sebagai uang pengganti untuk memiliki si perempuan dan untuk mendapatkan layanan karena pada prinsipnya pasangan suami istri adalah pasangan yang saling melayani dan dilayani. Sehingga diharapkan dengan adanya status mahar seperti ini apa yang menjadi tujuan utama sebuah keluarga membentuk keluarga yang sakinah mawaddah wa rahmah antara suami dan istri dapat terwujud. ${ }^{18}$

Muhammad Mutawalli al-Sya'rawi (1911-1998) menjelaskan, bahwa maksud saduqatihinna adalah mahar, sedangkan nihlah adalah pemberian. Apakah sidaq itu pemberian, jawabnya "tidak". Sidaq adalah hak dan ongkos pengganti digunakannya alat kelamin. Tetapi Allah ingin menjelaskan bahwa hendaklah pemberian mahar kepada perempuan seperti nihlah atau pemberian. Laki-laki menikah dengan perempuan bagi laki-laki mendapat kenikmatan pada dirinya, demikian juga perempuan. Keduanya memiliki hak yang sama untuk mendapatkan keturunan. Diharapakan seorang laki-laki tidak mengambil sesuatu dari mahar, karena perempuan itu akan diambil kenikmatannya dan juga terkadang mendapat anak darinya. Dia akan bekerja di rumah dan laki-laki akan bersusah payah keluar rumah, tetapi pemberian ini ditetapkan oleh Allah untuk memuliakan perempuan. ${ }^{19}$

Sementara Sayyid Quthb (1906-1966) menjelaskan bahwa maskawin dinamai oleh ayat ini saduqat bentuk jamak dari saduqah, yang terambil dari akar kata sadaqa yang berarti “kebenaran”. Ini karena maskawin itu di dahului oleh janji sehingga

${ }^{16} \mathrm{Abu} J a$ ‘far Muhammad ibn Jarir al-Thabari, Jami' al-Bayan 'an Ta’wìl Ayi al-Qur'an (Beirut: Dār alFikr, 2005), Jilid 3, 293.

${ }^{17}$ Muhammad Rasyid Ridha, Tafsir al-Manar, (Kairo: t.p, 1973), Jilid 4, 307-308.

${ }^{18}$ Khairuddin Nasution, Islam Tentang Relasi Suami dan Istri (Hukum Perkawinan I), Yogyakarta: ACADEMIA \& TAZZATA, 2004), 168.

${ }^{19}$ Mutawalli al-Sya'rawi Tafsir al-Sha 'raw i (al-Qahirah: Akhbar al-Yawm, 1999), Jilid 4, 2014. 
pemberian itu merupakan bukti kebenaran janji. ${ }^{20}$ Dapat juga dikatakan bahwa maskawin bukan saja lambang yang membuktikan kebenaran dan ketulusan hati suami untuk menikah dan menanggung kebutuhan hidup istrinya, tetapi, ia adalah lambang dari janji untuk tidak membuka rahasia rumah tangga, khususnya rahasia terdalam..$^{21}$ Mahar adalah simbol kejujuran, tanda persetujuan dan pemberian wajib yang tidak mengharapkan imbalan dan balasan ${ }^{22}$.

Quraish Shihab (L.1944) memperjelas makan saduqat. Maskawin dinamai saduqat diperkuat oleh lanjutan ayat, yakni nihlah. Kata ini berarti pemberian yang tulus tanpa mengharapkan sedikitpun imbalan. Ia juga dapat berarti agama, pandangan hidup, sehingga maskawin yang diserahkan itu merupakan bukti kebenaran dan ketulusan hati sang suami, yang diberikannya tanpa mengharapkan imbalan, bahkan diberikannya karena didorong oleh tuntunan agama atau pandangan hidupnya ${ }^{23}$.

Berdasarkan pengertian-pengertian tersebut dapat disimpulkan bahwa mahar (maskawin) adalah pemberian yang wajib diberikan oleh suami kepada istri dengan sukarela disertai dengan cinta dan kasih sayang tanpa mengharapkan imbalan. Kata nihlah yang didahului kata saduqat diikat oleh janji untuk membuktikan kebenaran cinta dan kasih sayang sehingga dengan ikatan janji itu maka terdoronglah atas dasar tuntuan agama untuk memberikan mahar secara suka rela tanpa mengharapkan imbalan. Mahar merupakan simbol kejujuran dan tanda persetujuan kedua belah pihak. Mahar diberikan kepada istri adalah merupakan kemuliaan dan kehormatan bagi perempuan.

\section{BESAR KECILNYA JUMLAH MAHAR}

Syariat Islam tidak memberikan batas minimal ataupun maksimal ukuran mahar karena ada perbedaan manusia antara kaya dan miskin, lapang dan sempit. Setiap tempat memiliki kebiasaan dan tradisi yang berbeda pula sehingga tidak ada batasan tertentu agar setiap orang dapat menunaikannya sesuai kemampuan, kondisi ekonomi dan adat keluarganya. ${ }^{24}$ Maka dibiarkanlah setiap calon suami menentukan jumlah mahar yang dianggap wajar, berdasarkan kesepakatan antara kedua keluarga dan sesuai dengan kemampuan dan keadaan keuangan dan kebiasaan di masing-masing tempat. Yang penting dalam hal ini adalah bahwa mahar tersebut haruslah sesuatu yang dapat diambil manfaatnya, baik berupa uang, atau sebentuk cincin atau berupa makanan, atau bahkan pengajaran tentang al-

\footnotetext{
${ }^{20}$ Muhammad Thahir Ibnu 'Asyur, al-Tahrir wa al-Tanwir, Jilid 4, 230.

${ }^{21}$ M.Quraish Shihab, Tafsir al-Misbah: Pesan, Kesan, dan Keserasian al-Qur'an (Jakarta: Lentera Hati,2008), Volume 2, 416.

${ }^{22}$ Hasbi Hj.Muh.Ali, Raihanah Hj.Azahari “Objektif Pemberian Mahar”dalam International Journal Fiqh, No.10 (2013), 59. http://umexpert.um/edu.my/file/publication/00002815_95293-pdf. (diakses 25 Nopember 2015).

${ }^{23}$ M.Quraish Shihab, Tafsir al-Misbah: Pesan, Kesan dan Keserasian al-Qur'an, Volume, 2, 416.

${ }^{24}$ Al-Sayyid Sabiq, Fiqh al-Sunnah (Kairo: Dar al-Fath li I'lam al-'Arabi, 1999), Jilid 2, 101-102.
} 
Qur'an dan sebagainya, sepanjang telah disepakati bersama antara kedua pihak. ${ }^{25}$ Maskawin terkadang berupa cincin besi, seuntai bunga mawar, atau kalung intan, sesuai dengan kadar kemampuan sang suami, ${ }^{26}$ berdasarkan QS al-Thalaq (65): $7:{ }^{27}$ Mahar istri-istri Rasulullah saw. lima ratus dirham. ${ }^{28}$ Mahar juga berupa sebentuk cincin besi, izar (sarung) atau mengajari perempuan beberapa ayat al-Qur'an.

Telah diriwayatkan oleh Sahl bin Sa'ad al-Sa'idi bahwa seorang perempuan datang kepada Rasulullah saw., lalu dia berkata, "Wahai Rasulullah, aku datang hendak menyerahkan diriku kepadamu. " Lalu Rasulullah saw. melihatnya dengan menaikkan dan menurunkan pandangan kepadanya, kemudian beliau menundukkan kepala. Ketika perempuan itu tahu bahwa Rasulullah saw. tidak memutuskan sesuatu pun mengenai dirinya, maka dia duduk. Lalu seorang laki-laki dari sahabat beliau berdiri seraya berkata: " Jika engkau tidak berhasrat kepadanya, maka kawinkanlah aku dengannya." Rasulullah saw. bertanya, " Apakah engkau memiliki sesuatu untuk maharnya? Dia menjawab, "Demi Allah tidak punya, wahai Rasulullah." Beliau berkata, " Pergilah ke rumah keluargamu, dan lihatlah barangkali engkau dapat memperoleh sesuatu." Lalu dia pergi, kemudian kembali lagi seraya berkata: Tidak ada wahai Rasulullah, saya tidak mendapatkan sesuatu pun." Rasulullah saw. berkata lagi: "Lihatlah, walaupun hanya sebentuk cincin besi." Lalu dia pergi, kemudian kembali lagi seraya berkata, " Tidak ada wahai Rasulullah, bahkan cincin besi pun tidak ada. Cuma ini izar (sarungku)" Sahl berkata, "Dan tidak mempunyai rida'(pakaian untuk menutup separo tubuh bagian atas)," setengahnya. "Lalu Rasulullah saw. berkata,"Apa yang engkau akan lakukan terhadap izarmu? Jika engkau pakai, maka dia tidak mendapatkan apa-apa, dan jika dia pakai maka kamu tidak mengenakan apa-apa." Maka duduklah laki-laki itu dalam waktu yang cukup lama. Kemudian dia pergi dan Rasulullah saw. melihatnya, lalu beliau menyuruh agar dia dipanggil. Setelah dia datang, beliau bertanya, "Apa yang engkau hafal dari al-Qur'an?" Dia menjawab,"Saya hafal surah

\footnotetext{
${ }^{25}$ Muhammad Bagir, Fiqih Praktis II Menurut al-Qur'ān, al-Sunnah, dan Pendapat Para Ulama (Bandung: Karisma, 2008), 131. Baca juga Zaitunah Subhan, Meggagas Fiqh Pemberdayaan Perempuan, 223.

${ }^{26}$ Muhammad Syarur, Dirasah Islamiyah Mu'asharah Nahw Ushul Jadidah li al-Fiqh al-Islami (terj) Sahiron Syamsuddin,Metodologi Fiqh Islam Kontemporer(Yogyakarta: eLSAQ, 2004), 437.

${ }^{27}$ QS. al-Thalaq (65): 7:

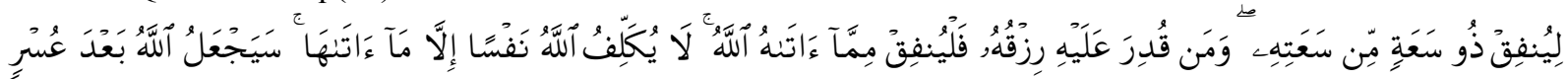

"Hendaklah orang yang mampu memberi nafkah menurut kemampuannya. Dan orang yang disempitkan rezkinya hendaklah memberi nafkah dari harta yang diberikan Allah kepadanya. Allah tidak memikulkan beban kepada sesorang melainkan apa yang Allah berikan kepadanya. Allah kelak akan memberikan kelapangan sesudah kesempitan".

${ }^{28}$ Diriwayatkan oleh Abu Salamah bin Abd al-Rahman bahwa dia berkata: "Aku berkanya kepada Aisyah, istri Nabi saw., Berapa besar maskawin Rasulullah saw.? Dia menjawab, Maskawin beliau kepada istriistri beliau adalah sebesar dua belas uqiyah dan satu nash. Tahukah kamu, apakah nash itu ? Aku menjawab, Tidak. Dia menjawab, "Setengah uqiyah. Semua itu berarti lima ratus dirham. Maka inilah maskawin Rasulullah saw. kepada istri-istrinya.
} 
ini dan surah ini (sambil menghitung surah-surah itu. Beliau bertanya, "Apakah engkau dapat membacakan kepadanya dengan hafalan? "Dia menjawab, "Bisa." Rasulullah saw. bersabda," Pergilah, aku telah mengawinkanmu dengannya dengan mahar ayat al-Qur'an yang ada padamu (yang engkau ajarkan kepadanya). ${ }^{29}$

Maharnya Fathimah binti Rasulullah Saw. adalah baju besi hut\}amiyyah Ali Karramallah wajhah, karena Ali tidak memiliki selainnya. Riwayat Ibnu 'Abbas, dia berkata:

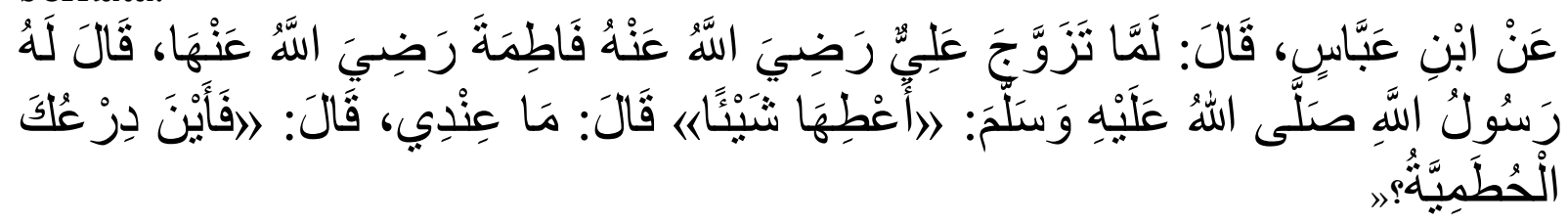

Artinya:

Dari Ibnu Abbas berkata: Ketika Ali r.a.kawin dengan Fathimah r.a, Rasulullah saw. berkata kepada 'Ali," Berikanlah sesuatu (sebagai maskawin) kepadanya."Dia menjawab, "Saya tidak punya apa-apa."Beliau bertanya, "Mana baju besi huthamiyyahmu? (HR. Al-Nasai). ${ }^{30}$

Hadith-hadith di atas menunjukkan bahwa mahar dalam perkawinan tidak harus berupa uang atau benda, tetapi boleh juag berupa manfaat apa saja, misalnya manfaat pengajaran tentang al-Qur'an. Yang penting dalam hal ini ada persetujuan dari calon istri, tidak bergantung pada sedikit atau banyaknya mahar tersebut. Meskipun demikian mazhab Hanafi memberi batas minimal mahar sebanyak 10 dirham. Sedangkan mazhab Maliki membatasinya 3 dirham. Namun pada hakikatnya, tidak ada dalil kuat yang dapat dijadikan dasar penetapan seperti itu, baik dalam al-Qur'an maupun hadith Nabi saw. ${ }^{31}$

Jadi, mahar (maskawin) menurut al-Qur'an bukan sebagai harga dari seorang perempuan. Oleh karena itu, tidak ada ukuran atau jumlah yang pasti. Ia bisa besar dan biasa kecil. Dalam sebuah hadith justru dikatakan bahwa sebaiknya jumlah maskawin tidak terlalu besar. Nabi saw mengatakan :

Artinya:

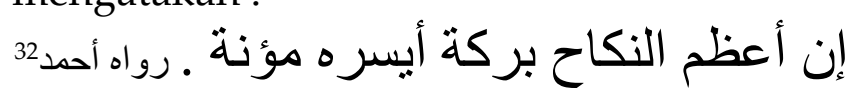

Keberkatan paling agung dari suatu pernikahan adalah maskawin yang mudah/ringan untuk diberikan.

Sebaliknya, pemberian maskawin secara berlebihan justru dilarang. Hal ini dimaksudkan agar tidak menimbulkan kesulitan bagi pemuda untuk melangsungkan perkawinannya. Mempersulit perkawinan bisa melahirkan

${ }^{29}$ Al-Imam Muslim, Sahih Muslim bi Sharh al-Nawawi (Beirut: Dar al-Kutub al-'Ilmiyyah, t.th.) Jilid 9, 211-214. Lihat juga Abu 'Abd Allah Muhammad bin Isma'il bin Ibrahim bin al-Mughirah bin al-Bardabazah alBukhari al-Ja'fi, al-Bukhari bi Hasyiyah al-Sanadi (Kairo: Dar al-Fikr, 2006), Jilid 3, 267.

30، Abd al-Halim Abu Shuqqah, Tahrïr al-Mar'ah, (terj). Kebebasan Wanita (Jakarta: Gema Insani, 1998), Jilid 5, 89. Baca juga Muhmmad Albar, Wanita Karir dan Timbangan Islam Kodrat Kewanitaan Emansipasi dan Pelecehan seksual, tej. Amir Hamzah Fahruddin, (Jakarta: Pustaka Azzam, 1998), 40.

${ }^{31}$ Al-Sayyid Sabiq, Fiqh al-Sunnah (t,tp: Dar al-Fath, t.th.), Jilid 2, 103.

${ }^{32}$ Ahmad Ibn Hanbal, Musnad al-Imam Ahmad ibn Hanbal (Beirut:Dar al-Fikr, t.th.), Jilid 4, 82. 
implikasi-implikasi yang buruk, atau bahkan merusak secara personal maupun sosial. Umar bin Khattab pernah menyampaikan bahwa ketika seorang laki-laki diharuskan memberi maskawin yang mahal kepada (calon) istrinya, boleh jadi ia akan menyimpan kebencian kepada perempuan itu. ${ }^{33}$ Sungguh buruk jika wali memaksakan jumlah tertentu untuk maskawin, yang boleh jadi memberatkan calon suami. Maskawin bukanlah harga diri seorang istri, tetapi ia adalah lambang kesediaan dan tanggung jawab suami memenuhi kebutuhan istri dan anakanaknya. ${ }^{34}$ Pemberian mahar yang terlalu besar atas permintaan dari pihak istri sama dengan jual beli barang yakni tak ubahnya menjual barang dengan harga yang tinggi, padahal akad nikah itu bukanlah akad jual beli.

\section{MEMBAYAR MAHAR SECARA TUNAI ATAU MENUNDANYA}

Mahar dalam hukum perkawinan Islam merupakan pemberian wajib dari mempelai laki-laki kepada mempelai perempuan, berupa uang atau barang, misalnya emas, tanah dan lain-lain yang diucapkan ketika dialangsungkan akad nikah. Mahar dalam hukum Islam tidak ditentukan besar kecilnya, tetapi didasarkan pada kemampuan pihak suami dan kerelaan pihak istri. Dalam ijab kabul mahar disebutkan tunai atau tidak tunai, jika disebut hutang, maka pihak suami wajib membayarnya sebagaimana hukum berhutang. Dengan tidak ada adanya kepastian jumlah, mahar yang diberikan kepada perempuan tersebut menurut ukuran umum atau kebiasaan setempat dan bahkan kemampuan laki-laki.

Mahar boleh dibayar secara tunai pada saat berlangsungnya akad pernikahan atau menundanya, ataupun membayar sebagiannya dan menundanya sebagian yang lain, berdasarkan persetujuan kedua belah pihak atau sesuai dengan tradisi setempat yang berlaku. Namun sebaiknya melunasinya atau -paling- sedikit membayar sebagiannya, setelah berlangsungnya akad nikah. ${ }^{35}$ Hal ini berdasarkan riwayat Ibnu 'Abbas r.a. bahwa Nabi saw. memerintahkan kepada Ali.ra. memberikan sesuatu kepada Fathimah r.a sebelum mereka berkumpul, berikut riwayat tersebut :

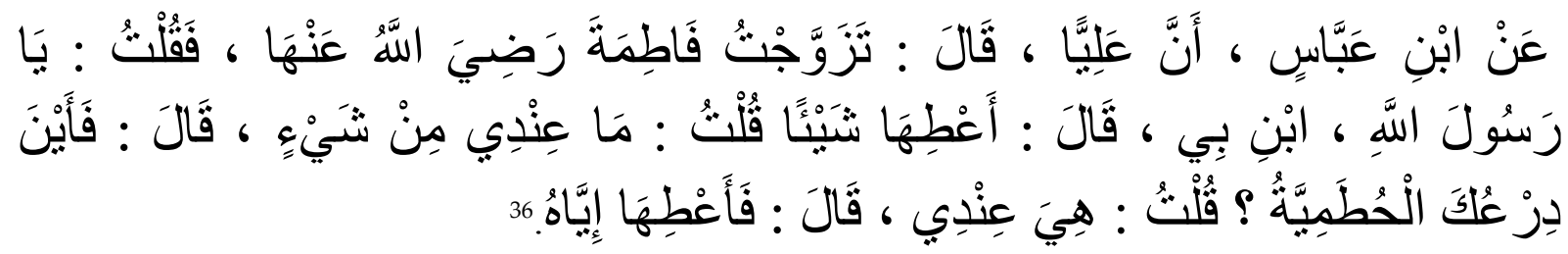

Dari ibnu 'Abbas r.a bahwa 'Ali telah berkata: saya telah menikahi 'Aisyah r.a.lalu Rasulullah berkata: "Berikanlah sesuatu kepadanya." Ketika itu 'Ali berkata: "saya tidak memiliki sesuatu." Maka Nabi saw. bertanya kepadanya, "Mana baju besi al-Huthamiyyah

\footnotetext{
${ }^{33}$ Husein Muhammad, Fiqh Perempuan Rafleksi Kiai atas Wacana Agama dan Gender, 109.

${ }^{34}$ M.Quraish Shihab, Tafsir al-Misbah, Pesan, Kesan dan Keserasian al-Qur'ān, Volume, 1, 514.

${ }^{35}$ Muhammad Bagir, Fiqih Praktis II Menurut al-Qur'ān, Al-Sunnah dan Pendapat para Ulama, 134-135. Baca juga al-Sayyid Sabiq, Fiqh al-Sunnah, Jilid 2, 104.

${ }^{36}$ Jalal al-Din al-Suyuthi Sunan al-Nasai'( Beirut: Dār al-Fikr, 1930), Jilid 3, 129-130.
} 
milikmu? 'Ali ra. berkata, ini baju huthaiyyahku. Maka Nabi saw. berkata "Berikanlah kepadanya. (HR. Al-Nasai').

Berdasarkan hadith di atas, sebagian ulama, antara lain al-Zuhri menyatakan bahwa si istri berhak menolak keinginan suaminya untuk "berkumpul" dengannya sebelum diserahkan mahar. Sementara sebagian lainnya seperti Ibnu Hazm dan Abu Hanifah menyatakan bahwa istri tidak berhak menolak selama ia telah merelakan ditundanya pemabayan mahar, semuanya ataupun sebagiannya ketika berlangsungnya akad nikah. Sebeb menurut mereka perempuan itu telah menjadi istrinya yang sah dengan adanya ijab kabul ${ }^{37}$.

Mencermati uraian tersebut dapat disimpulkan bahwa mahar harus ditetapkan seblum akad nikah besar kecilnya, boleh disebut dan boleh juga tidak disebut ketika melangsungkan akad nikah. Mahar disebut saduqah untuk membuktikan kejujuran suami kepada istrinya dan untuk merekatkan hubungan antara keduanya. Mahar juga disebut nihlah sebagai pemberian yang pantas pantas yang diserahkan dengan suka rela penuh keikhlasan karena untuk memuliakan perempuan.

Penulis setuju pembayaran mahar dengan tunai sebelum berkumpul, bukanlah mahar sebagai lambang pernikahan dan sebagai simbol cinta dan kasih sayang serta untuk kehormatan dan kemuliaan perempuan yang harus dibuktikan oleh seorang suami kepada istrinya bahwa ia benar-benar mencintai istrinya yang baru saja dinikahinya.

\section{E. KEWAJIBAN MEMBAYAR MAHAR SETENGAH DARI JUMLAH MAHAR}

Apabila terjadi perceraian sebelum berlangsungnya hubungan seksual (senggama) antara kedua suami istri, maka suami diwajibkan membayar setengah dari mahar yang telah ditentukan. Allah swt. berfirman dalam QS. al-Baqarah (2): 237:

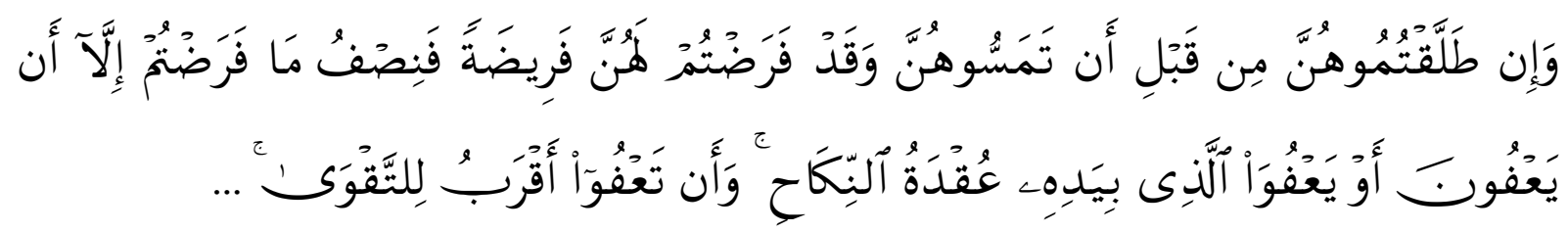

Terjemahnya:

Jika kamu menceraikan istri-istrimu sebelum kamu bercampur dengan mereka, padahal kamu sudah menentukan maharnya, maka bayarlah seperdua dari mahar yang telah kamu tentukan itu, kecuali jika istri-istrimu itu memaafkan atau dimaafkan oleh orang yang memegang ikatan nikah, dan pemaafan kamu itu lebih dekat kepada takwa. ${ }^{38}$

Qurasih Shihab menjelaskan ayat tersebut bahwa apabila perceraian dijatuhkan sebelum terjadi hubungan seks, tetapi telah disepakati kadar mahar sebelum

\footnotetext{
${ }^{37}$ Muhammad Bagir, Fiqih Praktis II Menurut al-Qur'an, al-Sunnah dan Pendapat para Ulama, 135. Bandingkan dengan al-Sayyid Sabiq, Fiqh al-Sunnah, Jilid 2, 104-105.

${ }^{38}$ Departemen Agama RI, al-Qur'an dan Terjemahnya, 58.
} 
perceraian, maka yang wajib diserahkan oleh suami adalah seperdua dari jumlah yang ditetapkan itu. Hal ini karena salah satu tujuan utama perkawinan belum terlaksana, yakni hubungan seks. ${ }^{39}$

Akan tetapi apabila jumlah mahar belum ditentukan sebelum percerian terjadi, maka wajiblah atas si suami memberikan mata' atau mut'ah (pemberian bersifat hiburan) kepada si istri yang diceraikan, sebagai pengganti kekecewaan hatinya atau gangguan psikologis yang mungkin dideritanya. Adapun jumlahnya tidak ditentukan, melainkan bergantung pada kelayakan dan kemampuan materil si suami. Firman Allah dalam QS. al-Baqarah (2): 236:

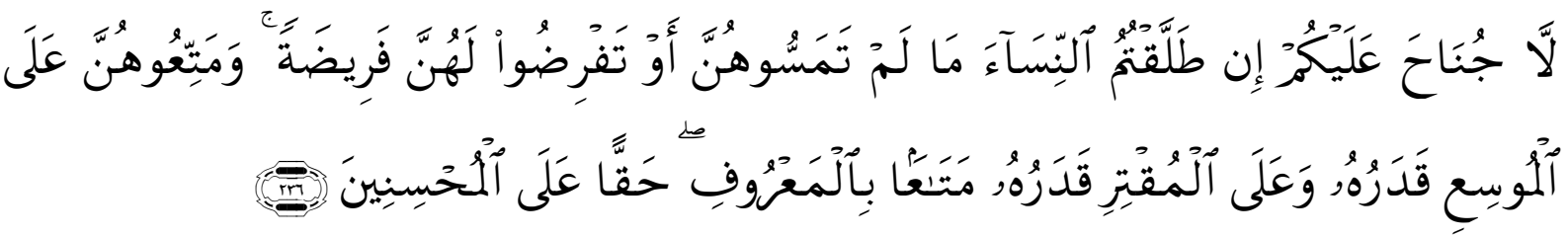

Terjemahnya:

Tidak ada kewajiban membayar (mahar) atas kamu, jika kamu menceraikan istri-istrimu sebelum kamu bercampur dengan mereka dan sebelum kamu menentukan maharnya. Dan hendaklah kamu berikan suatu mut'ah (pemberian) kepada mereka. Orang yang mampu menurut kemampuannya dan orang-orang miskin menurut kemampuannya (pula), yaitu pemberian menurut yang patut. Yang demikian itu merupakan ketentuan bagi orang-orang yang berbuat kebajikan. ${ }^{40}$

Para suami yang telah menceraikan istrinya sebelum bersetubuh, tidak berkewajiban membayar sesuatu, namun demikian sungguh bijaksana jika para suami memberikan sesuatu kepadanya, karena itu hendaklah kalian berikan suatu mut'ah (pemberian kepada mereka). Karena perceraian tersebut telah menimbulkan sesuatu yang dapat mengeruhkan hati istri dan keluarganya. Pemberian tersebut sebagaimana ganti rugi, atau lambang hubungan persahabatan dengan bekas istri dan keluarganya walaupun tanpa ikatan perkawinan. Jumlah yang diserahkan tidak ditentukan sesuai dengan kerelaan dan kemampuan bekas suami. ${ }^{41}$

Lanjut ia mengutip pandangan para pakar bahwa jika sudah melakukan hubungan (bersetubuh) dan telah menetapkan kadar maharnya maka suami berkewajiban memberikan kepada istrinya, demikian juga kepada istri yang diceraikannya, kadar mahar yang dijanjikan itu secara penuh. Apabila mereka telah bercampur sebagai layaknya suami istri, tetapi belum ditentukan kadar mahar sebelum menceraikannya, maka wajib dibayarkan oleh suami sejumlah yang pantas bagi perempuan yang status sosialnya sama dengan status sosial istri yang diceraikan itu. Kewajiban itu tetap berlaku, kecuali jika yang diceraikan itu

\footnotetext{
${ }^{39}$ M. Quraish Shihab, Tafsir al-Misbah, Pesan, Kesan dan Keserasian al-Qur'an, Volume 1, 515.

${ }^{40}$ Departemen Agama RI, al-Qur'an dan Terjemahnya, 58.

${ }^{41}$ M.Quraish Shihab, Tafsir al-Misbah, Pesan, Kesan dan Keserasian al-Qur'an, Volume 1, 514.
} 
memaafkan, yakni bersedia secara tulus untuk tidak menerimanya atau dimaafkan oleh orang yang memegang ikatan nikah. ${ }^{42}$

Al-Sya'rawi (1911-1998) menjelaskan QS. Al-Baqarah(2):241:43 bahwa setiap perempuan yang diceraikan suami dalam bentuk apa pun juga pasti dan harus mendapatkan hak mut'ah (pemberian). Hanya saja Allah telah memperincikan pemberian-pemberian tersebut dalam ayat-ayat yang telah disebutkan sebelumnya, yaitu jika kalian belum menentukan maskawin/mahar, maka berilah istri kalian sesuai dengan keadaan kalian yang kaya sesuai dengan rezeki yang diberikan Allah kepadanya dan yang miskin sesuai dengan kemampuannya. Tetapi jika kalian telah menentukan maskawin/mahar dan memberikannya, maka istri kalian mendapatkan seperdua darinya. ${ }^{44}$

\section{F. MAHAR HAK MUTLAK ISTRI}

Salah satu bukti tingginya perlindungan dan penghormatan Islam terhadap perempuan adalah dengan memberinya hak kepemilikan. Sebagaimana telah dijelaskan di masa jahiliyah hak perempuan telah dirampas dan kebebasannya dibelenggu. Wali perempuan dapat mengatur dengan leluasa hingga harta yang murni miliknya tanpa memberinya kesempatan sedikit pun untuk memiliki dan menggunakannya. Kedatangan Islam telah membebaskan perempuan dari belenggu ini. Islam menetapkan hak mahar baginya dan menjadikannya hak yang wajib diberikan calon suami kepadanya. Ayah ataupun orang terdekatnya tidak boleh mengambil bagian dari mahar tersebut sekecil apapun kecuali atas kerelaan dan persetujuan perempuan. ${ }^{45}$

Salah satu penelitian yang dilakukan oleh Rawal Priyanka dan Singh Jyoti di India tentang hubungan antara kekerasan rumah tangga dan tuntutan mahar. Di India Maskawin adalah mahar yang diberikan oleh orang tua pengantin perempuan ke keluarga mempelai laki-laki. ${ }^{46}$ Perlakuan buruk sering menimpa pengantin perempuan ketika mempelai laki-laki dan keluarganya tidak merasa puas dengan pembayaran mahar yang tidak menyenangkan. Hal ini berimplikasi kepada harga diri perempuan rendah dan status orang tua paling rendah dalam masyarakat. Mahar terkait dengan kekerasan bisa terjadi ketika maskawin atau mahar ini

${ }^{42}$ M.Quraish Shihab, Tafsir al-Misbah, Pesan, Kesan dan Keserasian al-Qur'an,Volume 1, 515-516.

${ }^{43}$ QS. al-Baqarah (2): 241:

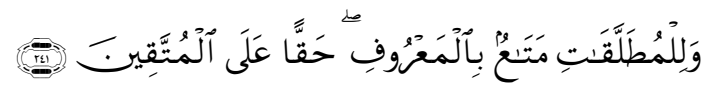

Kepada wanita-wanita yang diceraikan (hendaklah diberikan oleh suaminya mut'ah) menurut yang ma'ruf, sebagai suatu kewajiban bagi orang-orang yang bertakwa.

${ }^{44}$ Mutawalli al-Sya'rawi, Tafsir al-Sya'rawi,(Kairo: Shirkah al-Sawtiyah wa al-Mariyyah, t.th.) Jilid 2, 1029.

${ }^{45}$ Al-Sayyid Sabiq, Fiqh al-Sunnah, Jilid 2, 101. Baca pula Huzaemah Tahido Yanggo, Fikih Perempuan Kontemporer(Jakarta: Ghalia Indonesia, 2010), 119-120.

${ }^{46}$ Rawal Priyanka and Singh Jyoti, "Practice of Dowry and Domestic Violence." Research Journal of Recent Sciences, Vol. 3 (IVC-2014), 95. ISSN: 227-2502. http://isca.in/rjrs/archire/special-ivc-2014/17.ISCAIVC-2014-09FMS-05-pdf. (diakses 25 Nopember 2015). 
nampaknya tidak cukup untuk keluarga calon pengantin laki-laki. Mahar memberikan posisi anak perempuan di mata hukum untuk setiap gadis dalam sebuah keluarga. Pada tahun 2011 tercatat 8618 kematian perempuan yang berkaitan dengan sengketa mahar. Sebagian besar kasus dilaporkan perempuan mengalami penyiksaan psikologis, pelecehan. Alasan utamanya adalah pembayaran mahar yang rendah yang tidak mencukupi keinginan serakah mereka. ${ }^{47}$

Jadi perempuan di India tidak menikmati haknya dalam kepemilikan mahar. Keluarga calon pengantin laki-laki yang diberikan mahar oleh keluarga mempelai perempuan secara otomatis istri sama sekali tidak berhak atas mahar tersebut. Mereka masih seperti jaman dulu padahal mereka hidup pada abad ke-21. Setelah dan sebelum menikah mereka kehilangan jati dirinya kebutuhan dasarnya bergantung kepada keluarganya atau suaminya.

Mahar (maskawin) diberikan kepada seorang perempuan sebagai pemberian yang tidak mengharapkan pengembalian atau konsensi apapun. ${ }^{48}$ Mahar adalah sesuatu yang halus yang menaburkan benih cinta dalam memulai kehidupan yang baru. Pemberian ini sesuai dengan kemampuan dan pemberian ini merupakan lambang yang nilainya tidak terletak pada besar kecilnya, melainkan terletak di dalam perasaan orang yang memberikannya karena untuk memuliakan teman hidupnya. Oleh karena itu sama saja nilai spritual sebentuk cincin besi yang diberikan oleh orang miskin dengan satu kereta emas atau perak yang diberikan oleh orang kaya raya. ${ }^{49}$ Mahar bukanlah perdagangan perempuan, sebaliknya suatu pemberian yang bertujuan melindungi perempuan. Di samping menunjukkan penghormatan, penghargaan dan kemuliaan kepada para perempuan. ${ }^{50}$ Bagaimanapun, maka mahar adalah sesuatu yang wajib (pasti) yang tidak boleh pihak perempuan dihalangi untuk mendapatkannya, dijelaskan dalam QS. al-Nisa'> (4): 4:

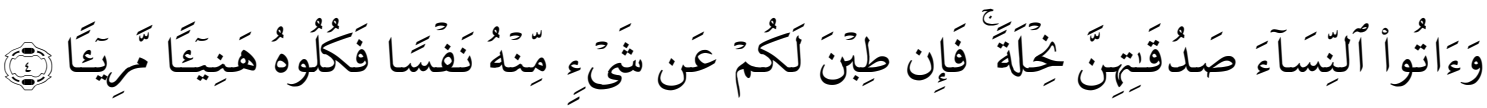

Terjemahnya:

Berikanlah maskawin (mahar) kepada wanita (yang kamu nikahi) sebagai pemberian dengan penuh kerelaan). Kemudian jika mereka menyerahkan kepada kamu sebagian dari maskawin

\footnotetext{
${ }^{47}$ Rawal Priyanka and Singh Jyoti, "Practice of Dowry and Domestic Violence." Research Journal of Recent Sciences, Vol. 3 (IVC-2014), 95

${ }^{48}$ Muhammad Syahrur, Nahw Ushul Jadidah li al-Fiqh al-Islami (terj), Sahiron Syamsuddin, Metodologi Fiqh Islam Kontemporer (Yogyakarta: eLSAQ Press, 2004), 437.

49، Abd al-al-Halim Abu Syuqqah, Tahrir al-Mar'ah fi 'Ashr al-Risalah (terj.) As'ad Yasin, Kebebasan Wanita,83.

${ }^{50}$ Hasbi Hj.Muh.Ali, Raihanah Hj.Azahari “Objektif Pemberian Mahar”dalam International Journal Fiqh, No.10 (2013), 59. http://umexpert.um/edu.my/file/publication/00002815_95293-pdf. (diakses 25 Nopember 2015).
} 
itu dengan senang hati, maka makanlah (ambillah) pemberian itu (sebagai makanan) yang sedap lagi baik akibatnya ${ }^{51}$.

Menurut Sayyid Quthb (1906-1966) maksud surah al-Nisa (4): 4 ini adalah memberikan hak yang jelas kepada perempuan dan hak keperdataan mengenai maskawinnya. Juga menginformasikan realitas yang terjadi dalam masyarakat jahiliyah di mana hak ini dirampas dalam berbagai bentuknya. Misalnya, pemegang hak maskawin ini di tangan wali dan ia behak mengambilnya untuk dirinya, seakanakan perempuan ini merupakan obyek jual beli, sedang si wali sebagai pemiliknya. ${ }^{52}$

Islam mewajibkan mahar (maskawin) dan memastikannya untuk dimiliki si perempuan sebagai suatu kewajiban dari laki-laki kepadanya yang tidak boleh ditentang. Islam mewajibkan si suami memberikan maskawin (mahar) sebagai “ nihlah" (pembeian yang khusus kepada perempuan) dan harus dengan hati yang tulus dan lapang dada, sebagimana halnya memberikan hibah dan pemberian. ${ }^{53}$

Sayyid Quthb (1906-1966) tidak menjelaskan secara eksplisit jenis mahar yang wajib diserahkan seorang suami kepada istirnya, Ia juga tidak menjelaskan waktu penyerahan mahar apakah boleh tunai atau diutang. Namun mayoritas ulama menyebutkan mahar itu dalam bentuk barang, boleh disebutkan dan diserahkan ketika akad nikah berlangsung dan boleh ditangguhkan (utang) sampai suami itu punya kemampuan. Quraish Shihab menyatakan dari segi kedudukan maskawin sebagai lambang kesediaan suami menanggung kebutuhan hidup istri, maskawin hendaknya bernilai materi, walau hanya cincin dari besi sebagaimana hadits Nabi saw. dan dari segi pengajaran ayat-ayat al-Qur'an. ${ }^{54}$ Contoh maharnya Fathimah binti Rasulullah saw. adalah baju besinya 'Ali Karramallah wajhah, karena 'Ali tidak memiliki selainnya, lalu ia menjualnya, kemudian diberikan kepada Fathimah sebagai mahar. Ada juga di antara perempuan sahabiyah yang maharnya berupa cinci besi, ada juga maharnya berupa ayat-ayat al-Qur'an yang kemudian diajarkan oleh suaminya. ${ }^{55}$

Mahar merupakan hak istri secara individual, bukan hak keluarga. Karena itu mahar ditetapkan sebagai kewajiban suami kepada istrinya, sebagai tanda keseriuasan serta menjadi simbol kasih sayang dari laki-laki kepada perempuan dalam suatu ikatan pernikahan. Di lain pihak mahar juga dapat dipahami sebagai penghormatan terhadap kemanusiaannya, dan sebagai lambang ketulusan hati untuk memperlakukannya secara ma'ruf. ${ }^{56}$ Al-Thabari (224-310 H.) menafsirkan

\footnotetext{
${ }^{51}$ Departemen Agama RI, al-Qur'an dan Terjemahnya (Jakarta: Yayasan Penyelenggara Penterjemah/Penafsir al-Qur'ān, 1971), 115.

${ }^{52}$ Sayyid Quthb, Fi Zilal al-Qur'an, Jilid I, 585.

${ }^{53}$ Sayyid Quthb, Fi Zilal al-Qur'an, Jilid I, 585.

${ }^{54}$ M.Quraish Shihab, Tafsir al-Misbah: Pesan dan Kesan, dan Keserasian al-Qur'an, (Jakarta: Lentera Hati, 2002), Volume 2, 416.

${ }^{55}$ Muhammad Albar, Wanita Karir dan Timbangan Islam Kodrat Kewanitaan Emansipasi dan Pelecehan Seksual, (terj) Amir Hamzah Fakhruddin (Jakarta: Pustaka Azzam), 1998), h. 40.

${ }^{56}$ Zaitunah Subhan, Menggagas Fiqh Pemberdayaan Perempuan (Jakarta: el-KAHFI, 2008), 224.
} 
potongan ayat ini menyatakan, berikanlah mahar kepada wanita (yang kamu nikahi) sebagai suatu pemberian yang wajib dan keharusan yang mesti dipenuhi." 57

و آتوا النسآء menyatakan bahwa suami wajib memberikan mahar kepada istri, karena faraj itu tidak dibolehkan kecuali dengan mahar yang diwajibkan, sama adanya disebutkan pada saat akad atau tidak disebutkan. Dan mahar itu pemanfaatannya bukanlah penggantian dengan harta, karena Allah menjadikan manfaat pernikahan itu adalah timbulnya syahwat dan lahirnya anak atas kerjasama antara suami istri, kemudian Allah memerintahkan kepada suami menyerahkan mahar kepada istri, hal yang demikian itu adalah pemberian dari Allah sebagai permulaan. Hal ini menjadi kesepakatan dan tidak ada pertentangan dalam hal itu. Ayat lain dalam firmannya (fankihuhunna bi izni ahlihinna wa atuhunna ujurahunna bi al-Ma'ruf." Nikahilah mereka atas izin keluarganya dan berikanlah upah mereka dengan ma'ruf. Maksudnya berikanlah kepada (istri-istri) mahar mereka. ${ }^{58}$

Mencermati penafsiran Wahbah al-Zuhayli (1.1932) dapat dipahami bahwa penyerahan mahar kepada perempuan hukumnya wajib, tetapi mahar itu boleh disebut atau tidak disebut pada saat berlangsung pernikahan, artinya bahwa mahar itu boleh saja tidak disebut pada saat aqad nikah. Penulis dalam hal ini tidak setuju jika mahar tidak disebut dan tidak disebut pula jumlahnya pada saat aqad nikah, apakah dibayar tunai atau tidak tunai (utang), karena hal ini dikhawatirkan dikemudian hari suami tidak mau membayar sampai punya anak, sementara Wahbah sendiri menyatakan bahwa tidak boleh melakukan hubungan (bersenggama) sebelum menyerahkan mahar kepada istri. Karena itu maka mahar itu wajib disebut pada saat akad nikah, walaupun bukan termasuk rukun nikah tetapi salah satu syarat sahnya pernikahan, demikian juga karena mahar itu adalah lambang pernikahan dan kemuliaan perempuan.

Ahmad Mustafa al-Maraghi (1883-1952) berpendapat, bahwa firman Allah ( wa atu al-Nisa' shaduqatihinna nihlah) pembicaraan ini ditujukan kepada para suami yakni berikanlah kepada perempuan-perempuan mahar yang telah kamu ikat dengan mahar sebagai pemberian yang berupa hibah, mahar itu sebagai lambang cinta kasih sayang, yang sepantasnya mawaddah itu berada pada suami istri, dan mahar itu adalah tanda kecintaan dan sebagai bukti eratnya hubungan dan ikatan disamping jalinan yang seharusnya meliputi rumah tangga yang layak dibangun. ${ }^{59}$

${ }^{57}$ Abu Ja'jar Muhammad bin Jarir al-Thabari, Jami ‘ al-Bayan 'an Ta'wil Ayi al-Qur'an (Beirut: Dar alFikr, 2005), Jilid 3, 292.

${ }^{58}$ Wahbah al-Zuhayli, al-Tafsir al-Munir, (Beirut-Libanon: Dar al-Fikr al-Mu'asyir, 1991), Jilid 4, 240.

${ }^{59}$ Menurut adat telah berlaku kebiasaan tidak cukup dengan pemberian ini, tetapi dibarengi dengan hadiah lainnya, maka dapat disaksikan, mereka mengantar bermacam macam hadiah dari bentuk makanan, pakaian, perabot rumah dan selainnya, dari apa yang dianggap baik menurut laki-laki untuk diberikan kepada perempuan yang dia ingin akan menjadikan sebagai pasangan hidupnya. Ahmad Mushthafa al-Maraghi Tafsir al-Maraghi (Kairo: al-Babi al-Halabi wa Awladuh,1946), Jilid 4, 184. 


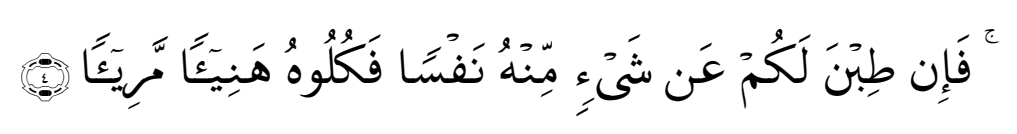

(Kemudian jika menyerahkan kepada kamu sebagian dari maskawin itu dengan senang hati, maka makanlah (ambillah) pemberian itu (sebagai makanan) yang sedap lagi baik akibatnya.

Al-Maraghi (1883-1952) menyatakan bahwa maksud potongan ayat ini, jika mereka (istri-istri) itu sendiri rela memberikan kepada para suami sebahagian dari mahar itu tanpa ada kesulitan, tipu daya, dan paksaan, maka suami boleh makan dengan riang gembira, tidak dianggap berdosa dan tidak pula berdosa jika para suami mengambilnya. Namun suami tidak boleh makan sedikitpun dari harta (mahar) istrinya, kecuali apabila suami mengetahui bahwa istri itu sendiri rela menyerahkan mahar itu kepada suami. Dan apabila suami itu minta sebahagian kepada istrinya tetapi istri itu diliputi rasa takut dan cemas terhadap pemberian apa yang diminta suami, maka mahar itu tidak halal bagi suami. ${ }^{60}$ Sejalan dengan alThabari (224-310 H.) berpendapat makna potongan ayat ini adalah jika istri-istrimu menyerahkan kepadamu wahai para suami, sebahagian dari mahar mereka, karena kebaikan hati mereka atas hal itu, maka makanlah (ambillah) pemberian itu (sebagai makanan) yang sedap dan baik akibatnya. ${ }^{61}$

Hal senada diungkapkan Wahbah al-Zuhayli (1932) bagi istri boleh memberikan sebahagian maharnya kepada suaminya, sama adanya dipegang sendiri atau berada dalam tanggungan, maka termasuklah hibah dan ibra,' akan tetapi sepantasnya bagi para suami waspada tehadap apa yang diberikan oleh para istri, karena syaratnya adalah dengan penuh kerelaan (dari lubuk hati yang paling dalam). Allah berfirman (fain thibna) dan tidak mengatakan ( fain wahabna) mengandung pengertian bahwa kerelaan dalam pengguguran mahar adalah dirinya rela memberikan kepada suaminya tanpa ada paksaan atau pendidikan, sama adanya (mu'asyarah), kebersamaan memperlakukan dengan baik atau dengan khadi'ah. ${ }^{62}$

Sayyid Qut\}b (1906-1966) menyatakan bahwa apabila istri merelakan maskawin (mahar) itu sebagian atau seluruhnya kepada suaminya, maka istri itu mempunyai hak penuh untuk melakukannya dengan senang dan rela hati, dan suami boleh menerima dan memakan apa yang diberikan istrinya itu dengan seang hati. Karena hubungan antara suami istri seharusnya didasarkan pada kerelaan yang utuh,

\footnotetext{
${ }^{60}$ Ahmad Mushthfa al-Maraghi, Tafsir al-Maraghi, Jilid 4, 184.

${ }^{61} \mathrm{Abu} J a$ 'far Muhammad bin Jarir al-Thabari, Jami ' al-Bayan 'an Ta’wil Ayi al-Qur'an, 293.

${ }^{62}$ Pengertian umum frase (fain tibna) menunjukkan bahwa hibah perempuan adalah memberikan maharnya kepada suaminya hukumnya boleh, sama adanya gadis (perawan) atau janda, menurut Jumhur Fuqaha. Malik mencegah hibah gadis adalah maharnya yang diberikan kepada suaminya Allah menetapkan hal itu diberikan kepada walinya, karena pemilikan itu adalah anak gadis itu. Apabila perempuan menggugurkan sebahagian maharnya dengan syarat waktu aqad nikah, agar tidak memperistrikan perempuan itu kemudian memperistrikannya maka perempuan itu tidak mendapat sedikitpun mahar, dalam riwayat Ibn al-Qāsim dari Malik; karena dia mensyaratkan terhadap laki-laki itu yang tidak boleh disyaratkan. Baca Wahbah al-Zuhayli, al-Tafsir al-Munir, Jilid 4, 241.
} 
kebebasan yang mutlak, kelapangan dada, dan kasih sayang yang tidak terluka dari kedua belah pihak. ${ }^{63}$

Dengan memberlakukan aturan seperti ini, Islam hendak menjauhkan sisa-sisa sistim Jahiliyah mengenai urusan perempuan dan maskawinnya. Hak-haknya terhadap dirinya dan harta bendanya, kehomatan dan kedudukannya. Pada waktu yang sama, Islam tidak mengeringkan hubungan antara perempuan dan suaminya, dan tidak menegakkan kehidupan rumah tangganya dengan semata-mata memeberlakukan peraturan secara kaku, melainkan memberinya kelapangan dan keleluasaan, saling merelakan, dan kasih sayang untuk mewarnai kehidupan bersamanya, dan untuk menyegarkan suasana kehidupannya. ${ }^{64}$

Menurut Sayyid Quthb (1906-1966) bahwa kewajiban suami memberikan maskawin (mahar) kepada istrinya sebagai "nihlah" adalah pemberian istimewa kepada perempuan" dengan hati yang tulus dan lapang dada sebagaimana pemberian sebagai hibah. Kemudian jika istri merelakan maskawin (mahar) sebahagian atau seluruhnya kepada suaminya, maka istri mempunyai hak penuh dengan senanghati dan rela, maka suaminya boleh menerimanya. Hanya saja Sayyid Quthb menyatakan bahwa jika istri merelakan maskawinnya (mahar) sebahagian atau seluruhnya. Pernyataan ini sepertinya tidak tepat kalau diserahkan mahar seluruhnya kepada suami, karena dalam ayat dijelaskan (fa in thibna lakum 'an sya'in minhu), kata minhu dalam ayat ini adalah menunjukkan min tab'i>diyah yang berarti "sebahagian." Oleh karena itu maka istri boleh memberikan maharnya kepada suami sebahagian saja.

Kerelaan istri menyerahkan kembali maskawin itu harus benar-benar muncul dari lubuk hatinya, karena ayat di atas menyatakan طبن yang maknanya "mereka senang hati" ditambah lagi dengan kata نفسا "jiwa" untuk menunjukkan betapa kerelaan itu muncul dari lubuk jiwanya yang dalam tanpa tekanan, penipuan dan paksaan dari siapa pun. ${ }^{65}$

Mencermati pernyatakan para mufassir tersebut dapat disimpulkan bahwa mereka sepakat menetapkan kewajiban suami memberikan mahar (maskawin) kepada istrinya sebagai "nihlah" yaitu pemberian" istimewa" kepada istri dengan hati yang tulus dan lapang dada tanpa rasa ragu dan khawatir sebagaimana pemberian sebagai hibah. Mahar adalah hak penuh istri, dia bebas menggunakannya dan bebas pula memberi sebagiannya kepada siapa pun termasuk kepada suaminya. Apabila dikemudian hari si istri merelakan sebagian atau seluruhnya mahar (maskawin) kepada suaminya dengan hati yang tulus tanpa dipengaruhi oleh pihak lain, maka suaminya boleh menerimanya dengan senang hati. Bahkan menurut mereka bolehlah ia makan dan juga boleh menggunakannya dengan tindakan lain, sesuai dengan kebutuhannya.

\footnotetext{
${ }^{63}$ Sayyid Quthb, Fi Zilal al-Qur'an, Jilid I, 585

${ }^{64}$ Sayyid Quthb, Fi Zilal al-Qur'an, Jilid I,585.

${ }^{65}$ M.Quraish Shihab, Tafsir al-Misbah Pesan, Kesan dan Keserasian al-Qur'an, Volume 2, 346.
} 
Lafaz فكلوه (makanlah) digunakan kalimat أكل yang artinya "memakan". Disisni mengandung pengertian bahwa mengambil manfaat yang tidak kembali kepada pemilik sesuatu yang bermanfaat tersebut, yakni mengandung pengerian adalah kepemilikan penuh. Asal penggunaan kata الأكل "memakan” dalam perbincangan itu adalah "isti" arah " untuk mengambil harta orang lain dengan pengambilan yang tidak akan kembali lagi kepadanya, karena "memakan "adalah jenis pengambilan manfaat yang paling tinggi sebagai penghalang atas sesuatu dan kembalinya sesuatu tersebut kepada pemiliknya. Akan tetapi kata ; memakan" yang disebutkan disini adalah untuk mengambil manfaat agar sesuai dengan firman Allah sebelumnya" dan janganlah kamu makan harta mereka bersama hartamu (QS. Al-nisa', 4:2) hal itu menunjukkan makna metapora (kiasan). ${ }^{66}$

Wahbah al-Zuhayli (1.1932) menjelaskan, suami halal mengambil apa yang diberikan oleh istrinya dengan syarat suka rela (dari lubuk hati yang dalam) tanpa ada sangkut pautnya dengan masalah dunia dan akhirat. Menurutnya kalimat maksudnya adalah bukan saja bentuk" makan", tetapi yang dimaksudkan adalah membolehkan dalam bentuk apapun. Itulah makna firman Allah "sesungguhnya orang-orang yang makan harta anak yatim seccara aniaya." Bukan yang dimaksudkan makan saja, akan tetapi karena tindakan makan adalah jenis tindakan bersenangsenang dengan harta, maka dianggap tindakan-tindakan itu dengan tindakan makan. ${ }^{67}$

Penulis setuju pandangan Ibnu 'Asyur dan Wahbah al-Zuhayli tersebut yang menyatakan bahwa kata أكلyang artinya"makan " digunakan disini, bisa diartikan dengan makna lain, mengingat dalam ilmu balaghah dikenal استعارةbukan terbatas pada makna kata itu saja, tetapi bisa diartikan dengan kata lain. Kata digunakan dalam ayat ini, karena pemanfaatan "makan" yang paling dominan dilakukan dan tindakan makan adalah jenis tindakan bersenang-senang dengan harta dalam kehidupan. Hal ini menunjukkan bahwa pemanfaatan dalam bentuk lain boleh saja dilakukan. Atau dengan kata lain dalam ayat ini kata أكل lebih tepat diartikan dengan makna metapora (kiasan) atau dengan istilah lain digiring ke pemahaman kontekstual bukanya ke makna harpiah atau tekstual.

Muhammad Thahir Ibnu 'Asyur(1879-1973) mempertegas bahwa kata saduqat (mahar) disebut dengan nihlah untuk menghindari makna mahar dengan jenis penggantian dan mirip dengan makna hadiah, karena mahar bukanlah pengganti dari kemanfaatan perempuan pada saat pernikahan dilaksanakan, karena nikah adalah aqad antara seorang laki-laki dengan perempuan yang bertujuan untuk bercampur dan mendapatkan ikatan yang kuat, serta penukaran hak-hak di antara suami istri. Hal ini lebih bernilai dari pada mahar harus diganti dengan harta. Allah menjadikan mahar sebagai hadiah yang wajib diberikan oleh suami untuk

\footnotetext{
${ }^{66}$ Muhammad Thahir Ibnu 'Asyur, al-Tahrir wa al-Tanwir, Jilid 4, 232.

${ }^{67}$ Wahbah al-Zuhayli, Tafsir al-Munir, Jilid, 4, 241-242.
} 
memuliakan istri. Mahar menjadi tanda keistimewaan dalam pernikahan, untuk membedakan antara pernikahan dengan perzinahan. ${ }^{68}$

Rasyid Ridha (1865-1935) menjelaskan bahwa ayat ini, selain ditujukan kepada para suami, juga lebih dikhususkan kepada para wali (karib dekat) semisal orang tua, paman dan kerabat yang memiliki hak asuh atau pemeliharaan yang menikahkan anak yatim atau selainnya agar tidak mengambil pemberian mahar tanpa seizin dan kerelaan mereka. Hal ini disinyalir al-Qur'an surah al-Nisa' (4:4).

Menurut Rasyid Ridha (1865-1935) kerelaan pemberian perempuan kepada para wali ditandai oleh beberapa hal, di antaranya pemberian itu tidak dilakukan dengan rasa kebencian, keterpaksaan dan perangai buruk. Sebaliknya para wali tidak boleh mengambil mahar mereka dengan cara mempermalukan dan cara menipu. Menurut 'Abduh (1848-1905) dalam pandangan sehari-hari dan cara secara kasat mata terkadang ada orang berpenampilan saleh dan senantiasa berzikir, namun mereka memakan mahar perempuan-perempuan mereka dengan cara-cara seperti disebutkan di atas dengan alasan para perempuan itu telah menyerahkan hartanya secara sukarela. Itu telihat jelas hanya Allah yang mengetahui apa yang mereka sembunyikan. Lanjut 'Abduh menyatakan kalau saja Allah memberi peringatan tegas kepada para suami agar berhati-hati, jika mengambil harta yang telah diberikan kepada istrinya yang akan mereka ceraikan bagaimana halnya dengan harta perempuan-perempuan yang diberikan dengan alasan sosial, kekerabatan dan kasih sayang? Tentu mereka harus berpikir beberapa kali sebelum mengambil dan memakannya, QS. al-Nisa' (4:20). ${ }^{69}$

Murtadha Mutahhari (1919-1979) menyatakan bahwa mahar adalah hak perempuan itu sendiri, bukan milik ayah atau saudara laki-lakinya. Al-Qur'an telah menunjukkan tiga pokok dasar dalam ayat ini. Pertama, mahar disebut sebagai s\}aduqah, tidak disebut mahar. Saduqah berasal dari kata sadaq, mahar adalah sidaq atau saduqah karena ia merupakan suatu pertanda kebenaran dan kesungguhan cinta kasih. Kedua, kata ganti (dhamir) hunna (adalah jamak perempuan) dalam ayat ini berarti bahwa mahar itu menjadi hak milik perempuan sendiri, bukan hak ayahnya, ibunya atau keluarganya. Ketiga, nihlah (dengan sukarela, secara spontan, tanpa rasa enggan), menjelaskan dengan sempurna bahwa mahar tidak mengandung maksud lain kecuali sebagai pemberian atau hadiah. ${ }^{70}$

Mencermati uraian para mufassir tersebut dapat disimpulkan bahwa mahar adalah pemberian yang wajib oleh suami kepada istri dengan suka rela disertai dengan cinta dan kasih sayang tanpa menghapkan imbalan. Mahar adalah hak penuh (mutlak) istri, tidak ada seorang pun yang berhak mengambilnya baik orang tuanya sendiri ataupun keluarga dekatnya. Namun apabila si istri rela dan ikhlas

\footnotetext{
${ }^{68}$ Muhammad Thahir Ibnu 'Asyur, al-Tahrir wa al-Tanwir, Jilid 4, 230-231. Muhammad Thahir Ibnu 'Asyur, Maqashid al-Syari'ah al-Islamiyyah, (Yordan: Dar al-Nafais, 2001), 436.

${ }^{69}$ Rasyid Ridha, Tafsir al-Manar, Jilid 4, 377.

${ }^{70}$ Murtadha Muthahhari, Nizam Huquq al-Mar'ah fi al-Islam (Teheran: Markaz I'lam al-Zikra al-Sadisah li Intishari al-Thawrah al-Islamiyah, 1985), 172.
} 
tanpa ada tekanan dari pihak lain menyerahan sebagian mahar itu kepada suami, maka suami boleh menerimanya, bahkan boleh memakannya dan boleh juga memanfaatkannya dengan tindakan lain sesuai dengan kebutuhan. Apabila suami minta sebagian mahar itu tetapi istri diliputi rasa ragu atau khawatir, maka suami tidak halal mengambil mahar tersebut, sebagaimana dalam ayat dinyatakan fain thibna lakum "jika mereka rela dan ikhlas tanpa ada keraguan" maka fakuluhu "bolehlah kalian mengambilnya" (memakannya).

\section{G. PENUTUP}

Al-Qur'an mengubah konsep pranata mahar karena ingin menempatkan perempuan pada kedudukan yang tinggi berdasarkan prinsip keadilan dan kemaslahatan dan ingin melindungi mereka dari segala bentuk diskriminasi dan menafikan hak-haknya, bukan tanpa alasan. Sebagaimana telah dijelaskan sebelumnya bahwa pada zaman jahiliyah tidak memberikan hak kepada perempuan, malah meletakkan perempuan pada kedudukan yang rendah dalam masyarakat. Perempuan tidak menikmati hak-haknya bahkan memperoleh perlakuan yang diskriminatif. Dengan kedatangan Islam perempuan mendapat kedudukan yang tinggi, terbebaskan dari bentuk diskriminasi serta dapat menikmati hak-haknya termasuk hak mahar. Dalam tafsir (khususnya tafsir kontemporer) ulama sepakat bahwa mahar adalah harta yang wajib diserahkan seorang suami kepada istri dan menjadi hak eksklusif istri, bukan hak orang tuanya atau kerabatnya. Tidak seorang pun yang boleh mengambil mahar istri kecuali atas persetujuan dan kerelaannya. Pemberian mahar seorang suami kepada istri yang menjadi hak miliknya telah menunjukkan berkeadilan jender.

\section{Daftar Pustaka}

Abu Shuqqah, 'Abd al-Halim. Tahrir al-Mar'ah fi 'Ashr al-Risalah (terj.) As'ad Yasin. Kebebasan Wanita. Jakarta: Gema Insani, 2000.

Albar, Muhammad. Wanita Karir dan Timbangan Islam Kodrat Kewanitaan Emansipasi dan Pelecehan seksual, (terj) Amir Hamzah Fakhruddin. Jakarta: Pustaka Azzam, 1998.

al-Ashfahani. Al-Raghib. Mu'jam Mufradat Alfaz al-Qur'an. Beyrut: Dar al-Fikr, 2010.

'Asyur, Muhammad Thahir Ibnu. al-Tahłrir wa al-Tanwir. Tunis: Dar Sahnun li alNasyr wa al-Tawzi', t.th. Jilid 4.

-------- . Maqasid al-Shari'ah al-Islamiyah. Yordan: Dar Nafais, 2001.

Bagir, Muhammad. Fiqih Praktis II Menurut al-Qur'an, al-Sunnah, dan Pendapat para Ulama. Bandung: Karisma, 2008. 
al-Bukhari, Abi 'Abd Allah Muhammad bin Isma'il bin Ibrahim bin al-Mughirah. alBukhari bi Hasyiyah al-Sanadi. Kairo: Da>r al-Fikr, 2006.

Departemen Agma RI. al-Qur'an dan Terjemahnya. Jakarta: Yayasan Penyelenggara Penterjemah/Penafsir al-Qur'an, 1971.

Ibn Hanbal, Ah\}mad. Musnad al-Imam Ahmad Ibn Hanbal. Beyrut: Dar al-Fikr, t.th. Jilid 4.

Ibn Hajjaj, Muslim. Sahih Muslim bi Syarh al-Nawawi, Beyrut: Dar al-Kutub al'Ilmiyah, th. Jilid 3.

al-Maraghi, Ahmad Mushthfa Tafsir al-Maraghi. Kairo: al-Babi al-Halabi wa Awladuh, 1946, Jilid 4.

Muthahhari Murtadha Nizam H\{uquq al-Mar'ah fi al-Islam .Teheran: Markaz I'lam alZikra al-Sadisah li Intishri al-Tsawrah al-Islamiyah, 1985.

-------- . The Right of Women in Islam. Teheran: World Organization fo Islamic Service, 1980.

Muhłammad, Husein. Figh Perempuan Refleksi Wacana Agama dan Gender. Yogyakarta: LKIS, 2001.

Nasution, Khairuddin. Islam Tentang Relasi Suami dan Istri (Hukum Perkawinan I), Yogyakarta: ACADEMIA \& TAZZATA, 2004).

al-Qurthubi, Abi. 'Abdillah Muhammad bi Ahmad al-Anshari. al-Jami' li Ahkam alQur'an. Beyrut: Dar al-Kutub al-'Ilmiyah, t.th.

Quthb, Sayyid. Fi Zilal al-Qur'an. Kairo: Dar al-Syuruq, 2011, Jilid 1, Cet. ke-39.

Sabiq, al-Sayyid. Figh al-Sunnah. Dar al-Fath li I'lam al-'Arabi, t.th. Jilid 2.

al-Sya'rawi, Mutawalli. Tafsir al-Sya'rawi. Kairo: Shirkah al-Sawtiyah al-Mar'iyyah, t.th.

Syahrur, Muhammad. Dirasah Islamiyah Mu'ashrah Nahwa Ushul Jadidah li al-Figh alIslami (terj.) Sahiron Syamsuddin. Metodologi Fiqih Islam Kontemporer. Yogyakarta: eLSAQ Press, 2004.

Syarifuddin, Amir. Hukum Perkawinan Islam Indonesia Antara Figh Munakahat dan Undang-Undang Perkawinan. Jakarta: Prenada Media, 2007.

Shihab, M.Quraish. Tafsir al-Misbah, Pesan, Kesan dan Keserasian al-Qur'an. Jakarta: Lentera Hati, 2008. Volume 2.

Subhan, Zaitunah. Menggagas Figh Pemberdayaan Perempuan. Jakarta: el-KAHFI, 2008. al-Suyuthi, Jalal al-Din. Sunan al-Nasa'i. Beyrut: Da>r al-Fikr, 1930.

al-Thabari, Abu Ja'far Muhammad bin Jarir. Jami'al-Bayan 'an Ta'wil Ayi al-Qur'an. Beyrut: Dar al-Fikr, 2005. Jilid 3.

Tahido Yanggo, Huzaemah. Fikih Perempuan Kontemporer. Jakarta: Ghalia Indonesia, 2010.

Umar, Nasaruddin. Ketika Fikih Membela Perempuan. Jakarta: Gramedia, 2014.

Zaydan, 'Abd al-Karim. al-Mufashshal fi Ahkam al-Mar'ah wa al-Bayt al-Muslim fi alSyari'ah al-Islamiyah. Beirut: Mu'assasah al-Risalah, 1993, Jilid 7.

al- Zuhayli, Wahbah. Tafsir al-Munir. Beirut: Dar al-Fikr al-Mu'shir, 1991, Jilid 4. 
al-Fiqh al-Islami wa Adillatuh. Damaskus: Dar al-Fikr, 1989. Jilid, 7.

Hj.Muh.Ali, Hasbi, Raihanah Hj. Azahari “Object Shari'ah dalam Pemberian Mahar “ dalam International Journal Fiqh, No. 10, 2013, 59. http://umexpert.um.edu.my/file/publication/ 00002815_95293.pdf.

Priyanka, Rawal and Singh Jyoti. "Practice of Dowry and Domestic Violemce." Dalam Research Journal of Recent Sciences, Vol.3, 2014, ISSN: 2277-2502. http://isca.in/rjrs/ archire/special-ivc-2014/17.ISCA-IVC-2014-09FMS-05-pdf. 